\title{
Jurnal Kedokteran
}

p-ISSN : 2686-1437

e-ISSN : 2686-0201

http://ejournal.ukrida.ac.id/ojs/index.php/Meditek/index

\section{Kajian Efek Rokok Elektrik terhadap Kesehatan}

\author{
Susana E. Sudradjat \\ Departemen Farmakologi, Fakultas Kedokteran dan Ilmu Kesehatan, Universitas Kristen Krida Wacana, \\ Jakarta, Indonesia. \\ Alamat korespondensi : susana.sudrajat@ukrida.ac.id
}

\begin{abstract}
Abstrak
Terkait dengan banyaknya pro dan kontra mengenai rokok elektrik, tinjauan pustaka ini berusaha mengkaji dampaknya bagi kesehatan. Ada berbagai jenis rokok yang tersedia di pasaran antara lain shisha, cerutu, rokok konvensional, dan rokok elektrik. Banyak pecandu rokok sekarang beralih ke rokok elektrik yang dianggap lebih aman, walaupun efek sampingnya hampir sama dengan rokok konvensional. Diketahui bahwa rokok meningkatkan morbiditas dan mortalitas akibat berbagai penyakit. Karena mengandung banyak zat yang sama, rokok elektrik juga dapat menyebabkan kerusakan organ tubuh dan menyebabkan adiksi. Dengan demikian, penggunaan rokok elektrik tidak dianjurkan..
\end{abstract}

Kata kunci : efek samping, rokok elektrik, rokok konvensional

\section{A Review of the Health Effects of Electric Cigarettes}

\begin{abstract}
The phenomenon of smoking has never stopped until now, with many pros and contras surrounding this phenomenon. In addition to conventional cigarettes, there are different types of smoking including shisha, cigars, and electric cigarettes. Many cigarette addicts are now switching to electric cigarettes, but the side effects are almost the same as conventional cigarettes. Studies found that there are various dangerous diseases that can be caused by smoking e-cigarettes including various organ damages and addiction. Therefore, e-cigarettes should be avoided.
\end{abstract}

Key words: electric cigarettes, conventional cigarettes, side effect. 



\section{Pendahuluan}

Setiap tahun, lebih dari 8 juta orang meninggal karena penggunaan tembakau, terutama di negara-negara berpenghasilan rendah dan menengah. ${ }^{1}$ Tembakau juga bisa membahayakan bagi yang bukan perokok. Asap tembakau berkontribusi terhadap penyakit jantung, kanker, dan penyakit lainnya, menyebabkan 1,2 juta kematian tambahan setiap tahunnya. ${ }^{1}$

\section{Rokok Elektrik}

Rokok elektrik terdiri dari tiga komponen, yaitu: plastic cartridge yang berfungsi sebagai alat pengisap dan cartridge yang berisi cairan, atomizer yang berfungsi untuk menguapkan cairan, dan batere. Cairan yang digunakan untuk menghasilkan uap pada rokok elektrik mengandung propilenglikol atau gliserin, bahan aromatik, dan nikotin cair dalam berbagai konsentrasi. $^{2}$ Ketika seseorang menghisap alat

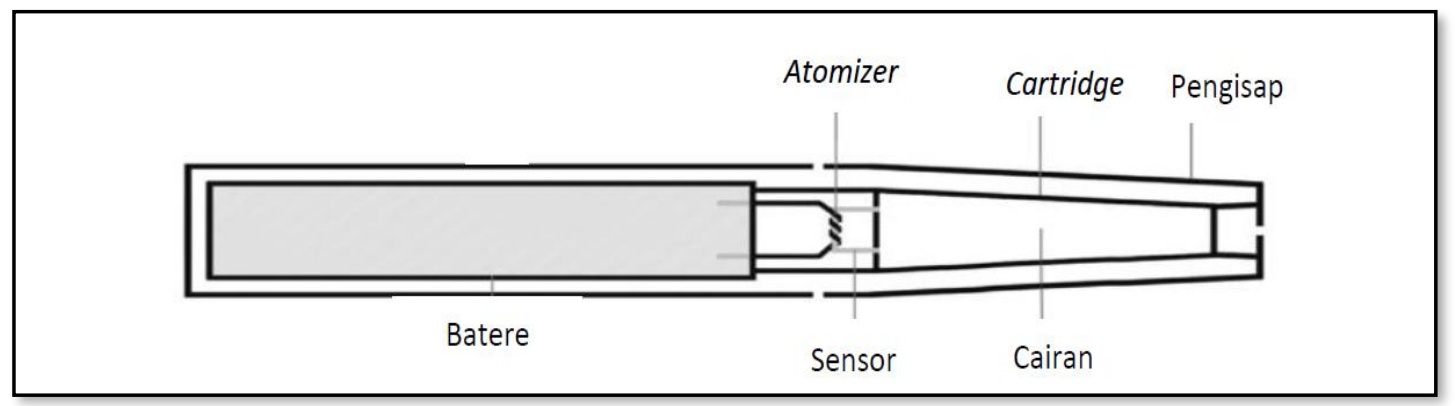

Gambar 1: Komponen Rokok Elektrik

Rokok konvensional yang dibakar berdampak negatif bagi tubuh. Beberapa tahun terakhir, banyak dari perokok yang beralih ke rokok elektrik. Rokok elektrik yang biasa disebut vape ini diklaim mampu membantu pecandu rokok tembakau untuk mulai berhenti merokok. Bahkan, ada yang percaya rokok elektrik dapat menghindari risiko penyakit jantung dan kanker seperti pada penggunaan rokok tembakau.

Rokok elektrik dirancang untuk menghantarkan nikotin pada perokok dalam bentuk uap, pertama kali dipasarkan di Cina pada tahun $2004 .^{2}$ Penyebarannya sangat cepat, pada tahun 2011 di Amerika sekitar 21\% orang dewasa yang merokok sigaret konvensional juga telah menggunakan rokok elektrik. ${ }^{3}$ Penelitian yang dilakukan di Kabupaten Semarang menunjukkan pengguna rokok elektrik ini sebagai alternatif untuk berhenti merokok. ${ }^{4}$ Namun ada juga kemungkinan uap yang dihasilkan rokok elektrik mengandung beberapa bahan yang dapat membahayakan kesehatan. Tinjauan pustaka ini meninjau rokok elektrik dari sudut pandang keamanan penggunaan. dan aliran udara terdeteksi oleh sensor, maka atomizer yang bersentuhan dengan cartdrige menjadi aktif sehingga menguapkan larutan nikotin. Aerosol nikotin yang dihasilkan kemudian dihisap oleh pengguna rokok elektrik tersebut. $^{2}$

Perokok konvensional mempunyai risiko sama dengan perokok lainnya jika memakai merek rokok yang sama, tapi tiap perokok rokok elektrik mempunyai resiko berbeda dengan perokok elektrik lainnya. Hal ini disebabkan karena banyaknya merek produk (kurang lebih 500) dengan 8000 bahan aroma (flavours) yang berbeda-beda. ${ }^{3}$ Risiko tidak hanya tergantung dari merek atau batch rokok elektrik, tapi tergantung aroma, pemanasan dan kebersihan rokok elektrik, dan faktor perokok itu sendiri.

Rokok elektrik makin popular sebagai pengganti rokok konvensional dengan persepsi sebagai alternatif yang aman. ${ }^{3}$ Persepsi umum yang menganggap rokok elektrik tidak berisiko adalah tidak benar karena banyaknya komposisi cairan dalam rokok elektrik. ${ }^{3}$ 
Kandungan rokok elektrik (e-cigarettes):

1. Golongan glikol antara lain propilen glikol dan gliserin. ${ }^{5}$

2. Nikotin dengan berbagai kadar. ${ }^{6}$

3. Partikel-partikel halus, dimana partikel yang berdiameter lebih kecil dari 2,5 mikrometer $\left(\mathrm{PM}_{2,5}\right)$ dapat meningkatkan resiko penyakit jantung, paru-paru dan asthma. ${ }^{7}$

4. Logam-logam antara lain kadmium, air raksa, timbal dan arsen. ${ }^{8}$

5. Tobacco-specific nitrosamines (TSNAs) yang bersifat karsinogenik. ${ }^{9}$

6. Karbonil seperti formaldehid, asetaldehid, aseton, propionaldehid dan butiraldehid.yang bersifat toksik dan karsinogenik. ${ }^{10}$

7. Senyawa organik yang mudah menguap dan bersifat karsinogenik seperti benzena, stirena, etil benzena dan toluena. ${ }^{11}$

8. Senyawa hidrokarbon aromatik polisiklik yang bersifat karsinogenik seperti benzopirena. ${ }^{12}$

9. Golongan fenol yang bersifat iritasi terhadap kulit, mata, dan membran mukosa setelah terpapar oleh inhalasi, dermal atau, oral. ${ }^{13}$

\section{Efek Rokok Elektrik terhadap Kesehatan}

Penelitian di Cina terhadap 45000 pelajar berumur 12-18 tahun yang menggunakan rokok elektrik menemukan berpengaruh pada saluran nafas. ${ }^{14}$ Pengguna rokok elektrik dilaporkan mempunyai gejala-gejala seperti iritasi mulut dan tenggorokan, batuk, vertigo, sakit kepala, gangguan saluran cerna, dan mual. ${ }^{15}$ Tapi ada juga yang melaporkan efek positif seperti melegakan pernafasan, mengurangi batuk, dan tiduk lebih nyenyak. ${ }^{16}$ Reaksi yang tidak diinginkan pada penggunaan 13 minggu dengan rokok elektrik lebih tinggi dari nikotin patch. ${ }^{17}$ Dermatitis kontak sering terjadi karena kandungan nikel dalam rokok elektrik ini. ${ }^{18}$ Penelitian pada manusia yang terpapar uap rokok elektrik ini menyebabkan obstruksi paru-paru dan peningkatan cotinine. ${ }^{19}$ Absorbsi nikotin pada orang yang terpapar uap rokok elektrik secara pasif hasilnya sama dengan asap rokok biasa. ${ }^{20}$ Rokok sigaret yang diduga menjadi pencetus kanker kandung kemih juga dikhawatirkan bahan pencetus tersebut terdapat dalam rokok elektrik. ${ }^{21}$ Analisis urin pengguna rokok elektrik mengungkapkan adanya dua senyawa karsinogenik, o-toluidin dan 2-naftilamin, dengan rata-rata 2,3 dan 1,3 kali lipat lebih tinggi dari rokok konvensional. ${ }^{22}$ Bahan-bahan tambahan seperti mentol dan sinamon dapat bersifat sitotoksik.Nikotin dapat menyebabkan stres oksidatif. Ekspresi gen yang terpapar nikotin dalam rokok konvensional sama dengan rokok elektrik. Uji viabilitas sel memperlihatkan penurunan kecepatan proliferasi sel yang diinkubasi dengan nikotin atau berbagai bahan aroma dari rokok elektrik mengalami penurunan dibandingkan dengan kontrol. ${ }^{23}$ Paparan nikotin pada rokok konvensional dan rokok elektrik terhadap saluran nafas menghambat reflek batuk. $^{24}$ Pengaruh rokok elektrik pada sistim kardiovaskular adalah peningkatan denyut nadi dan tekanan darah diastol. ${ }^{25}$

\section{Simpulan}

Kepustakaan menunjukkan bahwa rokok elektrik dapat menghasilkan uap yang mengandung nikotin, dan bahan- bahan lainnya yang dapat membahayakan kesehatan. Berdasarkan hal ini, penggunaan rokok elektrik tidak dianjurkan.

\section{Daftar Pustaka}

1. WHO Data. Tobacco fact sheet; No. 339. Available from: http://www.who.int /media centre/factsheets/fs339/en.

2. Goniewicz ML, Kuma T, Gawron M, Knysak J, Kosmider L. Nicotine levels in electronic cigarettes. Nicotine Tob Res. 2013;15(1):158-66.

3. Martínez-sánchez JM, et al. Perception of electronic cigarettes in the general population: does their usefulness outweigh their risks? 2015;1-7.

4. Behar RZ, et al. Identification of toxicants in cinnamon-flavored electronic cigarette refill fluids. Toxicol Vitr. 2014;28(2):198-208.

5. Afandi A, Kurniawan VA. Kajian Epidemiologi Pengguna Rokok Elektrik di Wilayah Kabupaten Semarang. Pro Health. 2019;1:9-13.

6. Etter JF, Bullen C. Saliva cotinine levels in 
users of electronic cigarettes. Eur Respir J. 2011;38(5):1219-20.

7. Pellegrino RM, et al. Electronic cigarettes: an evaluation of exposure to chemicals and fine particulate matter (PM). Ann Ig. 2012;24(4):279-88.

8. Feng Y, Kleinstreuer C, Rostami A. Evaporation and condensation of multicomponent electronic cigarette droplets and conventional cigarette smoke particles in an idealized G3-G6 triple bifurcating unit. J Aerosol Sci. 2015;80:58-74.

9. Geiss O, Bianchi I, Barahona F, BarreroMoreno J. Characterisation of mainstream and passive vapours emitted by selected electronic cigarettes. Int $\mathrm{J}$ Hyg Environ Health.2015;218(1):169-80.

10. Ohta K, Uchiyama S, Inaba Y, Nakagome H, Kunugita N. Determination of carbonyl compounds generated from the electronic cigarette using coupled silica cartridges impregnated with hydroquinone and 2,4dinitrophenylhydrazine. Bunseki Kagaku. 2011;60(10):791-7.

11. Shulei Han, Huan Chen, Xiaotao Zhang, Tong Liu, Ya'ning Fu, Levels of Selected Groups of Compounds in Refill Solutions for Electronic Cigarettes, Nicotine \& Tobacco Research. 2016;18(5):708-14.

12. Schober $\mathrm{W}$, et al. Use of electronic cigarettes (e-cigarettes) impairs indoor air quality and increases FeNO levels of e-cigarette consumers. Int $\mathrm{J}$ Hyg Environ Health.2014;217(6):628-37.

13. Farsalinos KE, et al. Nicotine levels and presence of selected tobacco-derived toxins in tobacco flavoured electronic cigarette refill liquids. Int $\mathrm{J}$ Environ Res Public Health. 2015;12(4):3439-52.

14. Wang MP, Ho SY, Leung LT, Lam TH. Electronic cigarette use and respiratory symptoms in Chinese adolescents in Hong Kong. JAMA Pediatr. 2016;170(1):89-91.

15. Ordonez J, Forrester MB, Kleinschmidt K. Electronic cigarette exposures reported to poison centers. Clin Toxicol. 2013;51:685.

16. Etter JF. Electronic cigarettes: a survey of users. BMC Public Health. 2010;10:231

17. Bullen $\mathrm{C}$, et al. Electronic cigarettes for smoking cessation: A randomised controlled trial. The Lancet, 2013;382(9905):1629-37.
18. Maridet C, Atge B, Amici JM, Taieb A, Milpied B. The electronic cigarette: the new source of nickel contact allergy of the 21 st century? Contact Dermatitis. 2015;73(1):4950

19. Flouris AD, et al. Acute impact of active and passive electronic cigarette smoking on serum cotinine and lung function. Inhalation Toxicology. 2013;25(2):91-101.

20. Flouris AD, et al. Acute effects of electronic and tobacco cigarette smoking on complete blood count. Food and Chemical Toxicology. 2012;50(10):3600-3.

21. Cumberbatch MG, Rota M, Catto JW E al. The role of tobacco smoke in bladder and kidney carcinogenesis. Eur Urol. 2016;70(458).

22. Fuller TW, et al. Comparison of bladder carcinogens in the urine of e-cigarette users versus non e-cigarette using controls. Sci Rep [Internet]. 2018;8(1):6-11.

23. Willershausen I, et al. Influence of Esmoking liquids on human periodontal ligament fibroblasts. Head Face Med. 2014;10(1):1-7.

24. Shivalingappa PC, Hole R, Van Westphal C, Vij N. Airway exposure to e-cigarette vapors impairs autophagy and induces aggresome formation. Antioxidants Redox Signal. 2016;24(4):186-204.

25. Qasim H, Karim ZA, Rivera JO, Khasawneh FT, Alshbool FZ. Impact of electronic cigarettes on the cardiovascular system. J Am Heart Assoc. 2017;6(9). 